\title{
Capetownski iskaz o predanju - graditi Kristov mir u podijeljenom i slomljenom svijetu - biblijski pogled na pitanje naroda s posebnim osvrtom na hrvatski kontekst
}

\author{
David Kovačević \\ Visoko evanđeosko teološko učilište, Osijek \\ david.kovacevic.cog@gmail.com
}

UDK: 27-1:2-44

Izvorni znanstveni članak

https://doi.org/10.32862/k1.14.1.6

\section{Sažetak}

Ovaj članak osvrće se na pojam nacije iz biblijske perspektive analizirajući one naglaske koje ističe Capetownski iskaz o predanju, posebice u poglavlju „Graditi Kristov mir u podijeljenom i slomljenom svijetu". Poseban osvrt bit će dan na temu nacije i nacionalizma $u$ hrvatskom kontekstu. U prvome dijelu daje se uvod u tri temeljne teorije nacionalizma, $u$ drugome dijelu analizira se svetopisamsko poimanje naroda. Nakon toga pozornost se usmjerava na dokument Capetownski iskaz o predanju i na tematiku izgradnje mira i pravde medu narodima, a u zadnjem dijelu nudi se tumačenje odnosa naroda i nacionalizama u hrvatskom kontekstu iz rimokatoličke i evanđeoske perspektive.

Cilj i svrha članka je analizirati biblijske i teološke naglaske dokumenta po pitanju nacije, dovesti ih u interakciju s drugim dokumentima i teološkim glasovima, i razumjeti njihovu primjenu unutar hrvatskog konteksta sa svrhom doprinosa evanđeoskom pokretu u Hrvatskoj u njegovoj misiji naviještanja Evanđelja u hrvatskom kontekstu. U članku se zaključuje kako postoje biblijski temelji koji pozitivno vrednuju egzistenciju naroda. Njih treba promatrati pozitivno iz perspektive Božjega stvaralačkog čina, negativno kroz prihvaćanje stvarnosti pada koji je utjecao i na egzistenciju naroda, te pozitivno iz perspektive Božje eshatološke budućnosti gdje i narodi imaju svoje mjesto.

Ključne riječi: nacija, nacionalnost, pomirenje, pravda, politička moć 


\section{Uvod}

Nacionalno je pitanje tema koja je još uvijek ne samo aktualna na našim prostorima već zahvaća društvene pore na različite načine. Istinsko pomirenje među narodima u jugoistočnoj Europi još izmiče i drži narode zatočenicima u smjelom kretanju prema budućnosti. Prepoznajući važnost i aktualnost ove teme za naše društvo, namjera je ovoga članka obuhvatiti teorijski dio vezan uz znanstveni pristup nacionalizmu, biblijski pristup pojmu nacija, adresirati problem religijskog nacionalizma te ponuditi kratku analizu određenih teoloških i eklezijalnih glasova koji progovaraju na ovu temu iz biblijsko-teološke i hrvatske kontekstualne perspektive. U tu svrhu, $\mathrm{u}$ prvome dijelu daje se uvod u tri temeljne teorije nacionalizma, a u drugome dijelu analizira se svetopisamsko poimanje pojma naroda. Nakon toga pozornost se usmjerava na dokument Capetownski iskaz o predanju i na tematiku izgradnje mira i pravde među narodima, a u zadnjem dijelu nudi se tumačenje odnosa naroda i nacionalizama u hrvatskom kontekstu iz katoličke i evanđeoske perspektive.

\section{Teorije nacionalizma}

Znanost o nacionalizmu složena je znanstvena disciplina koja na svoj predmet istraživanja ima različite perspektive. Unutar samog područja postoje brojna neslaganja i različite perspektive. Stoga, u uvodu ću ukratko dati prikaz tri temeljne teorije nacionalizma koje ću potom u članku detaljnije obraditi. Tri osnovna pristupa su: primordijalizam, modernizam i etno-simbolizam.

Özkırımli $(2000,64)$ opisuje primordijalnost kao pristup, a ne kao teoriju. Takav pristup smatra da nacija u suštini postoji sve dokle seže ljudsko sjećanje. Primordializam tvrdi da je pripadnost naciji na neki način dio ljudske prirode i ima antičko porijeklo.

Modernizam smatra kako nacija i nacionalizam imaju svoje porijeklo u kontekstu modernog vremena (Özkırımli 2000, 64). Gellner $(1983,138)$ definira nacionalizam kao poseban oblik domoljublja, razvijen u specifičnim društvenim uvjetima koje nalazimo samo u modernom svijetu, a karakteriziraju ih procesi poput Francuske revolucije, Industrijske revolucije itd. Taj nacionalizam definiraju čimbenici kao što su: kulturna homogenizacija, visoka razina pismenosti i svjesni pojedinci koji pristupaju vlastitoj kulturi bez posrednika. Gellner $(1983,138)$ to ovako sažima: „Ono što se tvrdi jest da je nacionalizam vrlo specifična vrsta domoljublja, ona koja postaje prožeta i dominantna samo pod određenim društvenim uvjetima, koji u stvari prevladavaju u svijetu moderne, i nigdje drugdje“.

Osnivač etno-simbolizma jest Anthony D. Smith. Njegov cilj nije bio stvaranje nove teorije u znanosti o nacionalizmu, već pružanje nove perspektive na istraživanje nacionalizma (Smith 2009, 1). Etno-simbolisti vjeruju da se identiteti 
današnjih naroda grade kroz „mitove, simbole, vrijednosti i sjećanja“ određene etničke skupine (Özkırımli 2000, 167). To je „simbolično nasljeđe pred-modernih etničkih identiteta u današnjim narodima" (Özkırımli 2000, 168).

U svjetlu ovih definicija usmjerimo se sada na hrvatski nacionalizam. Kao i drugi nacionalizmi, i on ima svoje posebnosti. Kakav su nacionalizam promicali hrvatski političari početkom devedesetih? Kada su hrvatski političari, predvođeni Franjom Tuđmanom, tisuću godina govorili DREAM o hrvatskoj državnosti, njihove su se tvrdnje temeljile na povijesnoj perspektivi. To je vidljivo kad promatramo događaje navedene u hrvatskom Ustavu iz 1991. godine. Ovu povijesnu perspektivu podržali su citiranjem hrvatske elite, plemstva i dokumenata koji su s njima povezani. Hrvatski jezik i kulturni identitet nisu uključeni u njihovu paradigmu. Bellamy $(2003,32-33)$ to naziva nedosljednim primordijalnim pristupom te tvrdi kako je razlog zbog kojeg su hrvatski političari 1990. godine stavljali naglasak na povijesnu narativu taj što nije bilo moguće utvrditi hrvatski etnički identitet: „Stoga se hrvatski narativ povijesne državnosti primarno bavi ustavnim uređenjem i političkim programima" (Bellamy 2003, 34-5).

Ivo Banac, hrvatski povjesničar i političar, bio je prvi koji je artikulirao da su se suvremeni hrvatski političari, uključujući Tuđmana, više usredotočili na povijesna pitanja, a ne na pitanja jezika, kulture i etničke pripadnosti:

Prvi je artikulirao historicizam hrvatskoga nacionalnog identiteta upravo Ivo Banac. U traženju književnih i povijesnih djela, koja su se bavila hrvatskim nacionalnim pitanjem, Banac je pokazao da takva djela teže pravnim, a ne lingvističkim ili kulturnim argumentima. Ta tendencija sugerira da su rani intelektualci i plemići vjerovali da će ideja povijesne državnosti nositi više naklonosti na habsburškim i mađarskim sudovima. To je značilo da su osnovna sredstva za nacionalnu integraciju bili ured bana i kontinuirana institucija Sabor. Međutim, Banac je sugerirao da je smanjivanje nadležnosti ovih dviju institucija u devetnaestom stoljeću oslabilo hrvatsko nacionalno tijelo i pridonijelo raznolikosti nacionalnih programa koji su se širili uoči Prvoga svjetskog rata (Bellamy 2003, 86).

\section{Biblijski pristup narodima}

Što se tiče biblijskog pogleda na koncept naroda, Block $(1986,492)$ navodi kako etimologiju naroda u Starom zavjetu pronalazimo u ova četiri termina: 'am (Suci 20,2); gôy (Iz 34,1a); lě ’ōm (Iz 34,1b); i 'mh (Ps 117,1). Prvi termin 'am odnosi se na rodbinske odnose kao otac, brat, muški rođaci, muški članovi plemena, svi članovi društva, ali i za sve članove naroda, uključujući žene i djecu. Drugi termin gôy koristi se općenito za narod ili za druge u smislu poganskih naroda. Ovaj termin nalazimo u listi naroda u Post 10; u odnosu prema kanaanskim plemenima u 
Pnz 7,1; beduinskim plemenima Iz 60,5; gradovi-države 2 Kr 19,13; narod-država (Izrael) i velike imperijalne države (Egipat i Babilon, Jr 25,17). Termini lě̀ ōm i 'mh uglavnom su arhaični i obično se koriste u kombinaciji s izrazom gôy.

Slično Blocku, iznosi i Christensen $(1992,1037)$, fokusirajući se na termine: 'am, gôy, lě 'ōm. Prema njemu, ovi se termini u Starom zavjetu naizmjence koriste kada se govori o narodima ili u jednini za specifični narod, uključujući Izrael. 'am se može prevesti i kao klan. Osnovno značenje riječi je srodstvo koje je temelj povezanosti grupe (Hamlin 1991, 515). U LXX se ta riječ na grčkom prevodi s ethne i laoi. U jednini riječ 'am obično se koristi za Izrael kao „narod Jahvin“ i tada se u LXX navodi kao „laoi“. U množini „ammim“ se u LXX navodi kao ethne $(\varepsilon ُ \theta v \varepsilon)$ i koristi za narode. Izraz gôy može se prevesti s „grupa“, a u LXX prevodi s ethne ili nacija. Taj se izraz ne odnosi na srodstvo, već na socijalne ili političke veze. Značenje riječi lě ōm je „tisuća“. Riječ se odnosila na grad koji je mogao proizvesti kontigent od 1000 vojnika. LXX ovaj termin prevodi s ethne. Riječ se kao sinonim koristi u proročkoj literaturi i psalmima (Christensen 1992, 1037).

Liverani $(1992,1031)$ upozorava kako biblijsku terminologiju o narodima ne treba poistovjetiti s modernom pojavom nacionalnih država u 18. i 19. stoljeću. Moderni termini kao što su „nacija“ $i$ „nacionalizmi“ imaju svoje posebnosti koje ne moramo nužno naći u antičkom vremenu Bliskog istoka. Teško možemo reći da je antički Izrael bio nacija u modernom smislu riječi. Liverani opisuje povijest nastanka modernih nacionalnih država kao rezultat modernih procesa kao što je Deklaracija o neovisnosti 1776. i Francuska revolucija 1791., a koje su rezultirale odvajanjem naroda od vladavine monarha i proglašavanjem nacionalnih i etničkih država sa svojim granicama. Prije modernog vremena imali smo različite izričaje, kao što su oni od gradova-država do carstava, od monarhija do feudalnog sustava, gdje je vladao suvereni gospodar koji je bio vlasnik zemlje i ljudi. Ljude $\mathrm{u}$ antičko vrijeme možemo zvati narodima, ali važno je poznavati razliku kako bi se izbjegli različiti anakronizmi. Njegova tvrdnja u skladu je s kompleksnošću studije o nacionalizmu, kako smo je ranije predstavili.

Osim govora o etimologiji, Block $(1986,492-93)$ teološki analizira biblijski pristup narodima definirajući nekoliko ključnih faktora u razumijevanju stvarnosti naroda na antičkom Bliskom istoku: etnicitet, teritorij, političko uređenje i teologiju. Pitanje etniciteta argumentira pozivanjem Izraela na zajedničko porijeklo u njihovu ocu Jakovu. To je vidljivo kroz opetovano ponavljanje fraze „sinovi Izraela“. Pitanje teritorija nije bila jednostavna odrednica budući da, općenito, ona nije bila toliko odrednica jednog etniciteta koliko je ovisila o sposobnosti kralja da objedini više teritorija. Primjer za to su Sjeverni Izrael i Juda. Sukladno tomu, i sama politika vrtjela se oko monarhističkog uređenja (Block 1986, 492-93).

Prema Blocku (1986, 493-94), ključnu ulogu u etnicitetu jednog naroda na antičkom Bliskom istoku imala je teologija. U kontekstu antičkoga Bliskog istoka se- 
mitski narodi sebe bi na različite načine povezivali sa zaštitničkim bogovima. Block tu ističe temeljnu razliku između Izraelaca i ostalih semitskih naroda. Semitski bi narodi određenu zemlju pripisivali određenom bogu i zato su smatrali kako je normalno štovati boga određenog područja, čak i više njih. Kod Izraelaca je to bilo drugačije jer su sebe vidjeli kao Božji narod, a zemlja je bila Božji dar njima.

Block $(1986,495)$ ističe nekoliko tekstova koji sažimaju Božji odnos prema narodima. Porijeklo nacija, prema hebrejskom svjetonazoru, opisano je u Pnz 32,8, gdje čitamo kako je Bog onaj koji je oblikovao nacije i podijelio im zemlju prema broju sinova Božjih. Jahve je nastavio širiti svoj autoritet nad narodima i seliti ih kako je htio (Iz 10,13; Am 9,7). Tekst liste naroda iz Post 10 jedan je od najobuhvatnijih antičkih bliskoistočnih spisa u kojem se objašnjava porijeklo naroda i njihova međusobna povezanost. Ovaj tekst smješta izbor Abrahama u širu ljudsku obitelj i opću ljudsku povijest. Abraham treba biti blagoslov svim narodima (Post 12,3), a prema Izl 19,5 Izrael treba biti kraljevsko svećenstvo, odnosno ima posredničku ulogu s obzirom na ostale narode između Boga i njih. To je, između ostalog, prema $1 \mathrm{Kr} 8,41-43$ bila i svrha Hrama.

Stoga, Block zagovara kako Izrael kao „narod“ treba razumjeti u prethodno navedenom antičkom kontekstu. Jahve je patrijarsima dao obećanje kako će Izrael dobiti status gôy ili naroda (Post 12), kako će njegovo potomstvo biti veliko (Post 17,6), kako će On biti Izraelov Bog (Post 17,7), da će im dati zemlju (Post 17,8) i kralja (Post 17,6). Zanimljivo je uočiti kako su Izraelove formativne godine protekle u Egiptu. Izrael je i tada bio gôy, iako bez zemlje i bez kralja, što znači da oni nisu bili uvjet njegova statusa kao gôy. Pojava kralja u Izraelu nije uvjetovala formaciju Izraela kao naroda budući da je Izrael i ranije postojao kao narod. Ovdje se samo radilo o usklađivanju Izraela s ostalim narodima. Jeremija 18,6-9 govori o uništenju i ponovnoj izgradnji nacije, ali Mihej govori kako će Jahve podići goy od bolesnih i On sam će biti njihov kralj (Block 1986, 494-95).

U Novom zavjetu za narode primarno se koristi riječ ethne (Mt 10,18; Rim 15,9-10) uzeta iz LXX, i to uglavnom za pogane. Za Izrael se koristi riječ laō

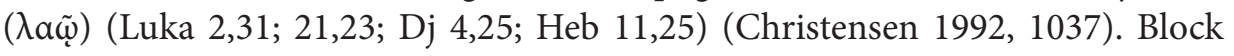
$(1986,496)$ ističe kako su u Novom zavjetu velike carske sile kao što su asirska, babilonska, perzijska, grčka i rimska utjecale na kretanja naroda. Zbog njih su narodi bliskog istoka doživjeli veliko miješanje identiteta. Židovi su iznimka zbog svojih vjerskih uvjerenja - čuvanja od pogana.

Iako u Mt 10,5 vidimo da Isus učenike šalje samo Izraelcima, nakon što ga izraelski narod odbija, vidimo drugačiji smjer u Mt 12,18. Taj redak, u kojem se navode citati iz Iz 42,2, ključan je redak za razumijevanje Isusova obnavljanja Izraela ili stvaranja novog Izraela. Tim tekstom Matej poistovjećuje Isusa sa „slugom Jahvinim“ koji donosi pravdu svim narodima (Block 1986, 496). Isus je za Mateja ispunjenje starozavjetnih obećanja o Mesiji, on ga identificira s Izraelom, i on je kao 
Mesija kralj novog Izraela. No specifičnost toga novog Izraela je u tome što on nije isključiv prema drugim narodima. Mesija Isus uključuje i druge narode, donoseći pravdu za sve, a u Mt 28,19 Isus šalje svoje učenike „svim narodima“ Mt 28,19.

U Dj 1,8 možemo uočiti nastavljanje ovog smjera. Crkva u početku svoje propovijedanje koncentrira samo na Židove. Promjena nastaje po progonstvu Crkve i poslije po Petrovoj viziji u $\mathrm{Dj}$ 10, a ključna promjena nastaje po Pavlovu obraćenju. On naglašava kako u Kristu više nema razlike između Židova i drugih naroda, i o tome, primjerice, piše u Gal 3,28: „Nema više: Židov - Grk! Nema više: rob - slobodnjak! Nema više: muško - žensko! Svi ste vi Jedan u Kristu Isusu“, te u Rim 10,12: „Nema uistinu razlike između Židova i Grka jer jedan je Gospodin sviju, bogat prema svima koji ga prizivlju“ (Block 1986, 496). Vrijednosti Mesijina Novog Izraela je jednakost za sve narode. Nema više razlike na nacionalnoj, društvenoj ili drugoj osnovi. Apostol Ivan u svojoj eshatološkoj viziji u Otk 5,9-10 predstavlja Kraljevstvo Božje kao domenu u kojoj će biti prisutni ljudi iz svakog plemena, jezika i naroda (Block, Bromiley 1986, 496).

Ovaj kratak pregled biblijskog pogleda na narode ukazuje nam kako se moderno razumijevanje naroda i nacije ne smije poistovjetiti s biblijskim razumijevanjem. Ipak, to ne znači da Sveto pismo ne poznaje pojam naroda. Ono ga izražava u svojoj terminologiji i kategorijama. Iz te perspektive ono je bliže primordijalnoj teoriji, gdje se narod veže uz zajedničko porijeklo i vladara. Specifična odrednica biblijskog razumijevanja naroda vezana je uz povezanost konkretnog naroda uz određeno božanstvo ili patrona. Izrael sebe kao narod razumijeva iz svoga odnosa s Jahvom budući da je On zaštitnik Izraela. Ipak, njegovo je gospodstvo puno šire. On je stvoritelj cijele zemlje i gospodar svih drugih naroda. Taj je smjer naznačen već u Starom zavjetu (Iz 42,2) i postaje očit u životu Isusa Krista (Mt 12,18) i u činu slanja njegovih učenika svim narodima (Mt 28,19). Ta otvorenost prema svim narodima vidljiva je u misiji Crkve i u eshatološkoj viziji Božjeg Kraljevstva, gdje ima mjesta za sve narode (Otk 5,9-10).

\section{Capetownski iskaz o predanju i njegov fokus na izgradnju mira i pravde među narodima}

Capetownski iskaz o predanju ${ }^{1}$ podijeljen je u dva glavna dijela: ispovijest vjere i poziv na djelovanje. $\mathrm{U}$ drugom dijelu, koji se odnosi na poziv na djelovanje, kao druga temeljna točka nalazi se dio koji nosi naslov „Graditi Kristov mir u podijeljenom i slomljenom svijetu“. Taj dio Iskaza razmatra na koji način mir, koji je Krist po svome križu ostvario između palog čovjeka i Boga, utječe na određena

1 U daljnjem tekstu Iskaz. 
područja ljudskog društva i Božjeg stvorenja. Konkretno, na koji način Kristov mir postaje stvarnost usred etničkih sukoba, siromaštva i izrabljivanja, kod osoba s invaliditetom i u kontekstu Božjega trpećeg stvorenja (The Lausanne Movement 2012,39). Ovaj dokument ne daje općeniti prikaz biblijske teologije o narodima i naciji, već se fokusira specifično na određena područja kao što su: prepoznavanje Božjega pozitivnog odnosa prema narodima kao prema njegovoj kreaciji, činjenicu udaljavanja naroda od njihove originalne svrhe, što je rezultiralo etničkim sukobima, te gradnji mira i pravednosti među narodima.

Jedan drugi dokument evanđeoske alijanse detaljnije je fokusiran na biblijsku teologiju o narodima: The Impact on Global Mission of Religious Nationalism and 9/11 Realities (LOP 50) (The Lausanne Movement 2004). Pregled biblijske teologije o narodima u tom dokumentu kreće dvama tekstovima koja smo već ranije naveli: Post 10,5 u kontekstu širenja Noinih sinova, gdje postoji lista naroda i Pnz 32,8 i Dj 17,26 gdje čitamo o tome kako je Bog stvorio narode (The Lausanne Movement 2004). U dokumentu se zatim navodi Post 11 i opis gradnje kule babilonske, gdje čitamo o zastranjenju i padu naroda. Radi se o realističnom pogledu na iskrivljeni nacionalizam, uprljan grijehom, koji svoj probitak vidi na štetu drugih. Potom, spominje se Post 12, gdje čitamo o Božjem nastojanju oko obnove naroda po Abrahamu koji treba biti blagoslov svim narodima. Nadalje, dokument govori o oblikovanju Izraela i Crkve kao Božjega duhovnog naroda ili kao o teološkoj stvarnosti, ne povijesno-organskoj. U Lk 3 vidimo paralelu listi naroda iz Post 10, a u Mt 28 veliko poslanje koje oblikuje našu misiju kao usmjerenu svim narodima. U Dj 2 na Pentekost predstavlja se početak ispunjavanja velikog poslanja kroz proklamaciju silnih djela Božjih na svakom jeziku naroda. Sadržaj je kršćanske proklamacije Krist koji donosi mir između čovjeka i Boga i među narodima po svome križu (Ef 2; Rim 1,14-15), stoga, Crkva ima zadatak raditi na tom pomirenju (2 Kor 5,18). Kraj ovoga pregleda završava eshatološkom stvarnosti u kojoj narodi imaju svoje mjesto u novom stvorenju prema Otkrivenju 13 (The Lausanne Movement 2004).

Čitajući Iskaz prepoznajemo tri temeljne odrednice u teologiji naroda. Prva je stvaranje. Etnička je raznolikost dar Božji (Pnz 32,8; Dj 17,26). Drugi je pad. Narodi su narušeni ljudskim grijehom i nastalo je neprijateljstvo među njima (Post 11). I treći je otkupljenje. Etnička će raznolikost biti sačuvana u novom stvorenju po obnovljenom Božjem narodu (Otk 7,9; 21,3; 21,22-24 ) (The Lausanne Movement 2012, 40).

Dokument priznaje neuspjeh Crkve s obzirom na njezin odnos prema etničkim identitetima. Crkva nije uvijek uspjela vrednovati etničku raznolikost $s$ obzirom na biblijsko svjedočanstvo u tri područja koja smo naveli (The Lausanne Movement 2012, 41). Stoga, dokument poziva pastore na poučavanje biblijskog svjetonazora o etničkom identitetu. Biblijski svjetonazor uključuje pozitivan stav o etničkom identitetu, shvaćanje da su naše etničke predanosti uprljane grijehom 
i kako je naš etnički identitet podređen novom identitetu u Kristu (The Lausanne Movement 2012, 41).

Također, dokument izražava žaljenje zbog sudjelovanja Crkve u etničkom nasilju i trenucima kada je šutjela zbog takvih čini. Iskaz priznaje kako je često i sama Crkva bila uključena u etničke sukobe, bilo direktno i aktivno ili indirektno i pasivno. To uključuje rasizam, holokaust, aparthejd, etničko čišćenje, međukršćanska, vjerska, politička i etnička nasilja. Crkva se treba pokajati za to. Mora biti ukorijenjena u kontekst, ali na način da kontinuirano izaziva nepravedne sustave (The Lausanne Movement 2012, 41). Kako bi Crkva bila sposobna vršiti svoju misiju, treba razumjeti biblijska načela pomirenja: Krist je ponio naše grijehe na križ, ne samo kako bi nas pomirio s Bogom već kako bi uništio neprijateljstva koja postoje među nama (The Lausanne Movement 2012, 41-2).

Dvije su ključne teme koje dominiraju ovim dokumentom: mir i pravda. Krist je svojim križem uspostavio mir između Boga i čovjeka (Ef 2,14-18; Rim 1,16-17; 3,23; 10,12-13). Taj mir ne odnosi se samo na mir između Boga i čovjeka već je neodvojiv od mira između čovjeka i čovjeka. Uključuje i mir između naroda. Narodi mogu međusobno naći mir u Kristu jer je Božji plan da se svi skupa nađemo u Kristu (Ef 1,10). U ostvarivanju mira među narodima po Kristu, ostvaruje se i Božje obećanje Abrahamu. To je blagoslov koji je obećan Abrahamu (Post 12 i Gal 3,6-9) (The Lausanne Movement 2012, 39-40). Birajući temu mira kao dominantnu, ovaj dokument ne ostaje na teologiji naroda općenito, nego ga zanima odnos među narodima u svijetu koji je ispunjen etničkim sukobima. Pravda je sljedeća tema. Iskaz vidi pomirenje s Bogom i pomirenje jednoga s drugim kao temelj traženja pravde. Tek po pomirenju, priznavanju svoje krivnje i primanju oprosta može se tražiti osnova za pravdu (The Lausanne Movement 2012, 40).

U zaključku, kao što je već istaknuto, Iskaz ne daje pregled teologije o narodima. Predstavlja biblijski pogled na narode iz tri temeljne perspektive: narodi kao dio Božjeg plana, narodi slomljeni grijehom i narodi kao dio Božje budućnosti u obnovljenom stvorenju. Glavne teme koje se protežu su mir i pravda kroz pomirenje Kristovim križem na vertikalnoj i horizontalnoj razini, priznanje Crkve vlastitih promašaja u pristupu narodima i etničkom identitetu te njezino sudjelovanje u etničkom pomirenju.

\section{Tumačenja odnosa naroda i nacionalizama u hrvatskom kontekstu iz katoličke i evanđeoske perspektive}

Nastavljajući se na temu nacionalizma i nacije te potrebe izgradnje Kristova mira u podijeljenom i slomljenom svijetu, u ovome dijelu članka želim analizirati neka tumačenja odnosa naroda i nacionalizama iz rimokatoličke i evanđeoske perspektive. 


\subsection{Katolička perspektiva o narodu i nacionalizmu}

Postoje različiti dokumenti na temelju kojih možemo razumjeti katolički stav o narodu, naciji i nacionalizmu. Primjerice, Steven Grosby ukazuje na sljedeće dokumente: Leo XIII's Sapientiae Christianae (1890); Pius XI's Mit Brennender Sorge (1937); Benedict XV's letter Cum Polaniae rebus (1920); Pius XI's / Allocution to the College of Cardinals / Benedetto il Natale (1930); Pius XII's Summi Pontificatus (1939) (Grosby 2016). Kontekst ovih enciklika bio je ili poslijeratni (Prvi svjetski rat) ili predratni (Drugi svjetski rat). Razvijene su u kontekstu sukoba među narodima pa su isticale univerzalno bratstvo čovjeka i Boga kao zajedničkog oca čovječanstva. Ključni su elementi, koje Grosby (2016) iščitava u ovim dokumentima, kako Katolička Crkva radi distinkciju između ljubavi prema narodu kao dobru pojavu, a dio je stvorenog poretka i radikalne ideologije nacionalizma koja napredak svoga naroda izgrađuje na štetu drugih naroda. Grosby (2016) to ovako opisuje:

U naučavanje Crkve, kao što je to vidljivo iz navoda Lea XIII. u dokumentu Sapientiae Christianae (1890), koje donosi tu kratku analizu, patriotizam se smatra nečim prirodnim i, kao takav, podložan je prirodnim zakonima koji potiču „svakoga građanina da se suoči sa smrću za svoju rodnu zemlju“. Ta prirodna povezanost, koja je temeljnica patriotizma, opisana je od strane Tome Akvinskoga u djelu Summa kao „načelo bivanja“, „Pobožnost se proteže na našu zemlju u toj mjeri da je ona za nas načelo bivanja“ (Third Article on Piety). Pod „načelom bivanja“ Akvinski i Crkva prepoznaju da ljudska bića žive u društvu, a izraz je ljudske naravi da to i tako čine. Prema tomu, patriotizam, kao povezanost sa svojom zemljom i narodom, manifestacija je ljudske prirode iako su organizacijski oblici te prirodne manifestacije povijesno različiti te variraju od gradova-kraljevstva do regije i do nacije. ${ }^{2}$

Prema Grosbyjevoj analizi možemo zaključiti kako Katolička Crkva vidi ljubav prema domovini kao prirodnu i kao Bogom dani poredak čovjeka i društva.

Robert W. McElroy (2017) ističe ove elemente u rimokatoličkoj teologiji nacija:

2 The Teachings of the Church as was seen in the quotation from Leo XIII's Sapientiae Christianae (1890), which introduced this brief analysis, patriotism is understood by the Church to be natural, and, as such, to be subject to the natural law that enjoins "every good citizen to face death for his native land." This natural attachment, constitutive of patriotism, was described by Aquinas in the Summa as a "principle of being," "Piety extends to our country in so far as the latter is for us a principle of being" (Third Article on Piety). By "principle of being," Aquinas and the Church recognize that human beings live in society, and that it is an expression of human nature for humans to do so. Thus, patriotism, as the attachment to one's own land and its people, is a manifestation of human nature, even though the organizational expressions of that natural manifestation vary historically, ranging from city-kingdom to region to nation (Grosby 2016). 
Prema socijalnom nauku Crkve, ljubav prema domovini jest vrlina. Zbirka socijalnog nauka Crkve jasno ističe kako „načelo solidarnosti zahtijeva da muškarci i žene našeg vremena njeguju veliku svjesnost o tome da su dužnici svome društvu čiji su dio.“ I u svojoj poticajnoj poruci narodu Poljske pod nazivom „Mojim ljubljenim sunarodnjacima“, Papa Ivan Pavao II. progovara o istinskom patriotizmu usred ugnjetavanja i previranja: „Ljubav prema našoj domovini nas ujedinjuje i mora nas ujedinjavati unatoč svim razlikama. Ona nema ništa zajedničko s uskogrudnim nacionalizmom ili šovinizmom. To je pravo ljudskoga srca. To je mjera ljudske plemenitosti." ${ }^{3}$

McElroy ističe kako je ljubav prema domovini vrlina. Ta vrlina nema ništa zajedničko s uskim nacionalizmima koji se razvijaju na štetu drugih (McElroy 2017).

Uspoređujući Grosbyja i McElroyja, jasno vidimo kako Katolička Crkva ima primarno pozitivan stav prema ljubavi prema vlastitu narodu, naciji i domovini. Ipak, s druge strane, Katolička Crkva uočava devijacije u odnosu prema vlastitu narodu koje se odražavaju na štetu drugih naroda u obliku nacionalizma i rasizma. Papa Pavao VI. (1967) je u svojoj enciklici „Populorum progressio“ o tome progovorio na sljedeći način:

Postoje prepreke stvaranju pravednijega društvenog poretka i razvoju sveopće solidarnosti: nacionalizam i rasizam. Potpuno je prirodno da narodi koji su tek nedavno stekli političku neovisnost budu snažno ljubomorni na svoje novostečeno, ali lomljivo jedinstvo te da čine sve da ga sačuvaju. Također, sasvim je prirodno za narode s dužom tradicijom kulture da budu ponosni na svoju baštinu. No taj hvalevrijedan stav trebao bi biti oplemenjen ljubavlju, ljubavlju prema cijeloj ljudskoj obitelji. Neumjereni ponos vlastitim narodom razjedinjuje narode i postavlja prepreku njihovoj istinskoj dobrobiti. ${ }^{4}$

Enciklika, dakle, ističe kako su nacionalizam i rasizam prijetnja pravoj ljubavi

3 In Catholic social teaching, the love of country is a virtue. The Compendium of the Social Teaching of the Church states clearly that "the principle of solidarity requires that men and women of our day cultivate a greater awareness that they are debtors of the society of which they have become a part." And in his moving message to the people of Poland entitled "My Beloved Countrymen," Pope John Paul II spoke of true patriotism amid the cauldron of oppression and upheaval: "Love of our motherland unites us and must unite us above all the differences. It has nothing in common with narrow nationalism or chauvinism. It is the right of the human heart. It is the measure of human nobility."

4 There are other obstacles to creation of a more just social order and to the development of world solidarity: nationalism and racism. It is quite natural that nations recently arrived at political independence should be quite jealous of their new-found but fragile unity and make every effort to preserve it. It is also quite natural for nations with a long-standing cultural tradition to be proud of their traditional heritage. But this commendable attitude should be further ennobled by love, a love for the whole family of man. Haughty pride in one's own nation disunites nations and poses obstacles to their true welfare. 
prema vlastitu narodu i naciji. Prava ljubav prema vlastitu narodu je onoliko prava koliko postoji ljubav i prema cijeloj ljudskoj obitelji.

Papa Ivan Pavao II., kod svoje posjete Hrvatskoj 1994. godine, u svome obraćanju hrvatskom narodu, ukazao je na to kako nas II. Vatikanski koncil u svojoj konstituciji Lumen Gentium uči kako Crkva nije samo sakrament jedinstva s Bogom već i jedinstva cijelog ljudskog roda (Papa Ivan Pavao II. 1994, 24). Ideja je, dakle, ukazati na to kako nas mir s Bogom poziva graditi mir i ljubav prema drugim narodima. Ivan Pavao II. istaknuo je kako Hrvatska, kao mlada država i demokracija, ima podršku od Rima, pogotovo u mirnom suživotu s drugim narodima. Podsjetio je kako je hrvatski narod obećao još papi Agatonu da će s drugim narodima živjeti u miru (Papa Ivan Pavao II. 1994, 19). Hrvatskom narodu želi mir, i da se nastoji pomiriti. No, da bi pomirenje bilo moguće, trebamo oprostiti, ali i tražiti oproštenje (Papa Ivan Pavao II. 1994, 19-20). Teme koje je Papa u svojoj posjeti Hrvatskoj 1994. godine otvorio su: mir, praštanje i jedinstvo cijelog ljudskog roda kroz biblijske slike Božjeg očinstva i/ili slike Božje kao osnovnog identiteta, ali i bogatstva koje proizlazi iz činjenice različitosti naroda (Papa Ivan Pavao II. 1994, 24).

Sažetak rimokatoličkog učenja je pozitivan stav prema narodu i naciji, ili domoljublju, ali negativan stav prema nacionalizmu. Ljubav prema svome narodu je prirodna, ali mržnja prema drugim narodima nije dobra. Osnovna je ideja da treba njegovati ljubav prema cijelom čovječanstvu jer smo svi stvoreni na sliku Božju, a ljubav prema vlastitoj naciji treba doprinijeti oplemenjivanju cijelog čovječanstva. Lumen Gentium (1998, 93-5) ističe kako je Crkva sakrament jedinstva cijelog čovječanstva, sakrament koji poštuje razlike. Stoga, Crkva mora biti aktivni faktor u izgradnji mira i pomirenja među narodima. Temeljna misao kod katoličkih autora i dokumenata sastoji se u tenziji pozitivizma koji se sastoji u ljubavi prema vlastitu narodu i izopačenosti nacionalizma.

\subsection{Evanđeoska perspektiva o narodu i nacionalizmu}

Sada želim istaknuti neke evanđeoske elemente u teologiji o narodima u dijalogu s Miroslavom Volfom i Peterom Kuzmičem. Kao što smo vidjeli, katolički autori, potaknuti kontekstom rata i nemira među narodima, razvijali su teologiju ljubavi prema naciji, ali i ljubavi prema ljudskom rodu općenito. Na tome tragu Miroslav Volf bavi se analizom zašto religije u većini slučajeva ne vrše tu funkciju mirotvorstva među narodima, štoviše zašto religije postaju i jedan od faktora sukoba. Volf ukazuje na one situacije u kojima religija skončava u sukobu, bilo da je njezin katalizator ili sukob podržava šutnjom.

Volf navodi teoriju Thomasa Hobbesa koji je još 1651. godine opisao tri osnovna razloga zbog kojih ljudi ulaze u sukobe i nasilje: „profit, sigurnost i ugled“. Stvar je, dakle, u zloj ljudskoj naravi (Volf 2015, 27-8). Kritičari religije 
tvrde kako je religija četvrti razlog sukoba. Branitelji religije priznaju taj potencijal u religiji, ali također govore kako je religija u stvarnosti ambivalentna te da sve ovisi o ljudima koji je koriste, o njihovoj zloj naravi (Volf 2015, 27-8). Volf se zapravo ne slaže ni s jednima ni s drugima. Tvrdi da i jedni i drugi propuštaju razumjeti prave razloge zašto religije ulaze u sukobe, a prema njegovu mišljenju, to je povezivanje religije s političkom moći (Volf 2015, 29-30). Religije na Balkanu, s početka 1990-ih godina, bile su u toj kušnji. Volf tvrdi kako u esenciji svjetske religije nisu političke, ali one to postaju združujući se s političkom moći (Volf 2015, 32). Prema Volfu, religije se združuju s političkom moći jer nisu zadovoljne svojim statusom svjedoka istine u koju vjeruju, već žele upotrijebiti političku moć kako bi svoju istinu nametnuli protivnicima i svladali ih (Volf 2015, 30).

Najvažniji razlog hoće li religija i njezini sljedbenici okončati u sukobu jest razina do koje se religija identificira s određenim političkim projektom i njegovim političkim zastupnicima (Volf 2015, 33). Ključno pitanje kod Volfa je što prevladava religijom i njezinim vjernicima i vođama? Prevladava li identifikacija s političkim projektom ili identifikacija s njezinom suštinom. Ako prevladava identifikacija s političkim projektom, ona je toliko izvjesna okončati u sukobu. Prevladava li njezina unutarnja suština, ona će postati faktor mira (Volf 2015, 33-4).

I u ovom trenutku Volf postavlja dilemu. Trebaju li onda religije izbjegavati javni angažman i postati dio privatne sfere? Za Volfa, politička identifikacija i javni angažman nisu isto. Religija može obogatiti politiku i javni diskurs, a opet se ne poistovjetiti s njom. Volf tu daje primjere Čilea, Indonezije, Filipina i Poljske. Kako ne bi podlegle kušnji političke identifikacije, a time i legitimaciji nasilja, prema Volfu, religije trebaju njegovati zdravu neovisnost o političkoj vlasti i ostati autentične sebi kako ne bi postale „politički ili kulturni“ resurs (Volf 2015, 34). Volf također pravi razliku između „debelih“ $i$ "tankih“ religija. „Debele“ su one koje su vjerne svojoj suštini i tako obogaćuju društva, a "tanke“ su one koje se poistovjećuju s društvom i tako ne služe ni sebi ni društvu (Volf 2015, 34).

Kuzmič postaje konkretniji kada je riječ o religijama na našim prostorima. Navodi problem među nacionalnim crkvama koji se pojavio nakon dolaska demokracije u Istočnu Europu, a koji se sastoji u tome da su se Crkve pokušale vratiti na „kvazikonstantinski model odnosa Crkve i države“ (Kuzmič 2012, 87). Kuzmič objašnjava kako su se nacionalne Crkve nakon pada komunizma, nakon dugo godina progonstva, našle u prilično čudnim okolnostima, gdje su im do tada komunistički vladari davali bezrezervnu podršku i javne privilegije bez usporedbe u ostalim demokratskim društvima (Kuzmič 2012, 87).

Kuzmič govori kako je promjena iz „komunističke ideologije“ $\mathrm{u}$ „nacionalističku ideologiju“ vodila u djelomično opravdano otkriće „etno-religijskih identiteta“, ali je promjena iz „totalitarizma u plemenski mentalitet“ dovela u pitanje 
demokratske procese i ljudska prava, pogotovo ranjivih manjina (Kuzmič 2012, 87). Kuzmič u suštini ukazuje na nesnalaženje crkava u novim demokratskim okolnostima i na povođenje za mitom i političkom ideologijom političara. Takav je odnos posebno utjecao na smanjivanje demokratskih procesa i prava manjina.

\section{Zaključak}

Temeljni je cilj ovoga članka bio razumjeti smjernice Iskaza s obzirom na njegovo poglavlje „Graditi Kristov mir u podijeljenom i slomljenom svijetu“ i njegov odnos prema konceptu naroda. Analizirajući biblijski pregled teologije o narodima i pristup Iskaza, možemo zaključiti kako postoje tri temeljne teze: egzistencija naroda je rezultat Božjeg plana, odnosi među njima narušeni su grijehom, što rezultira sukobom i neprijateljstvom, narodi su otkupljeni križem Kristovim i sudjelovat će u obnovljenom Božjem stvorenju. Nadalje, članak je ukazao na to kako se rimokatolički i evanđeoski dokumenti bave suštinom religije pokušavajući teološki promišljati narode: rimokatolički dokumenti ukazuju na tenziju između pozitivnog odnosa prema narodima izraženu domoljubljem ili patriotizmom te devijaciju izraženu nacionalizmom. S gledišta evanđeoske teologije, istaknuli smo Volfa i Kuzmiča koji adresiraju problem kako crkve ne sudjeluju u gradnji mira, već postaju generatori sukoba.

Kristov mir donosi preduvjete za prave odnose među narodima. Kristov je mir činjenica, ali i zadatak koji Crkva ima u svijetu. Božji je cilj dovesti sve skupa u i po Kristu, i to je evanđeoska misija (The Lausanne Movement 2012, 39). Crkva ima ulogu u Božjoj obnovi i transformaciji naroda, i kao takva treba prepoznati svoje greške u ispravnom vrednovanju i odnosu prema narodima. U svojoj misiji ne smije biti vođena združivanjem s političkom moći, kao što na to upozorava Volf, niti političkim oportunizmom, kao što upozorava Kuzmič, već Božjim pozivom koji je izražen biblijskom teologijom naroda.

U članku se potvrđuje kako postoje biblijski temelji koji pozitivno vrednuju egzistenciju naroda. Njih treba promatrati pozitivno iz perspektive Božjega stvaralačkog čina, negativno kroz prihvaćanje stvarnosti pada, koji je utjecao i na egzistenciju naroda, te ponovo pozitivno iz perspektive Božje eshatološke budućnosti, gdje i narodi imaju svoje mjesto. Sukladno tomu, ovo je poziv Crkvi, pa i konkretnoj Crkvi u Hrvatskoj, da živi Evanđelje u svome odnosu prema narodu i narodima.

\section{Literatura}

Bellamy, A. J. 2003. The formation of Croatian national identity. Manchester: 
Manchester University Press.

Block, D. I. 1986. „Nations“. U: Geoffrey W. Bromiley, ur. The International Standard Bible Encyclopedia, str. 492-96. Grand Rapids: William B. Eerdmans Publishing Company.

Christensen, D. L. 1992. „Nations“. U: David Noel Freedman, ur. The Anchor Bible Dictionary, Volume 4 K-N, str. 1037-1049. New York: Doubleday.

Drugi vatikanski Koncil: Dokumenti (Sv. 1). 1998. Lumen Genitum. Zagreb: Kršćanska sadašnjost.

Gellner, E. 1983. Nations and nationalism. Oxford: Billing \& Sons Ltd.

Grosby, S. 2016. National Identity, Nationalism, and the Catholic Church. https://www.oxfordhandbooks.com/view/10.1093/ oxfordhb/9780199935420.001.0001/oxfordhb-9780199935420-e-61 (pristupljeno 19. veljače 2020).

Hamlin. E. J. 1991. „Nations“. U: George Arthur Buttrick, ur. The Interpreter's Dictionary of the Bible, str. 515-23. Nashville: Abingdon Press.

Kuzmič, P. 2012. „Christianity in Eastern Europe“. U: Charles E. Farhadian, ur. Introducing World Christianity, First Edition, str. 77-90. New Jersey: Blackwell Publishing.

Liverani, M. 1992. „Nationality and Political Identity“. U: David Noel Freedman, ur. The Anchor Bible Dictionary, Volume 4 K-N, str. 1031-1037. New York: Doubleday.

McElroy, R. W. 2017. What is the Catholic response to the rise of nationalism? https://www.americamagazine.org/politics-society/2017/01/24/what-catholic-response-rise-nationalism (pristupljeno 12. studenog 2019.).

Özkırımli, Umut. 2000. Theories of Nationalism. New York: St. Martin's Press.

Papa Ivan Pavao II. 1994. Govori u Hrvatskoj 10. i 11. rujna 1994. Zagreb: Kršćanska sadašnjost.

Papa Pavao VI. 1967. Populorum Progressio, On the Development of Peoples. http://w2.vatican.va/content/paul-vi/en/encyclicals/documents/hf_p-vi_ enc_26031967_populorum.html (pristupljeno 12. studenog 2019.).

Smith, A. D. 2000. "Theories of Nationalism. Alternative Models of Nation Formation". U: Leifer, M., ur. Asian Nationalism, str. 3-4. London: Imprint Routledge.

Smith, A. D. 2009. Ethno-symbolism and Nationalism. A cultural approach. New York: Routledge.

The Lausanne Movement. 2004. „The Impact on Global Mission of Religious Nationalism and 9/11 Realities (LOP 50)“. https://www.lausanne.org/con- 
tent/lop/the-impact-on-global-mission-of-religious-nationalism-and-911realities-lop-50 (pristupljeno 15. ožujka 2019.).

The Lausanne Movement. 2012. Capetownski iskaz o predanju. Zagreb: Protestantsko evanđeosko vijeće u RH.

Volf, M. 2015. Religije, identiteti i sukobi. Concilium, Vol. 51, No. 1. 25-34.

\author{
David Kovačević
}

\title{
The Cape Town commitment - building Christ's peace in a divided and broken world - a biblical view on the question of nations with spe- cial attention on the Croatian context
}

\begin{abstract}
This article looks at the notion of the nation from a biblical perspective by analyzing those emphases highlighted by The Cape Town Commitment, especially in its chapter "Building Christ's Peace in a Divided and Broken World." Special attention will be given to the topic of nation in the Croatian context. The first chapter gives an introduction to the three fundamental theories of nationalism, the second analyzes the biblical understanding of nations. In the third chapter attention is drawn to The Cape Town Commitment and theme of peacebuilding and justice among nations. In the last chapter the author brings interpretations of the nation and nationalisms in the Croatian context from a Roman Catholic and Evangelical perspective.

The purpose of the article is to analyze the biblical and theological emphases of the document concerning the nation, to interact with other documents and theological voices, and to understand their application within the Croatian context in order to contribute to the evangelical movement in Croatia in its mission of proclaiming the gospel in the Croatian context. The article concludes that there are biblical foundations that positively value the existence of nations. They should be viewed positively from the perspective of God's work of creation, negatively through the acceptance of the reality of the fall that affected the existence of nations, and again positively from the perspective of God's eschatological future, where nations have their place.
\end{abstract}

